\title{
Visitors' Perception of High-rise Building Effect on the Scenery of Traditional Gardens: A Case Study in Hama-rikyu Gardens, Tokyo
}

\author{
Buket Senoglu $^{1, *}$, H. Ekin Oktay ${ }^{2}$, Isami Kinoshita ${ }^{1}$ \\ ${ }^{1}$ Department of Environmental Science and Landscape Architecture, Faculty of Horticulture, Chiba University, 648 Matsudo, \\ Matsudo City, 271-8510, Chiba, Japan \\ ${ }^{2}$ Department of Landscape Architecture, Architecture and Design Faculty, Van Yuzuncu Yil University, Van, Turkey
}

Copyright $\bigcirc 2018$ by authors, all rights reserved. Authors agree that this article remains permanently open access under the terms of the Creative Commons Attribution License 4.0 International License.

\begin{abstract}
This study was carried out in a traditional Japanese garden namely Hama-rikyu Gardens which is one of the important heritage sites in Tokyo city. Hama-rikyu Gardens is a stroll type garden (kaiyu-shiki teien) which was originally designed to have borrowed sceneries (Shakkei) of nature elements in its surroundings. However, with the urbanization phenomena in the last decades, modern high-rise buildings have surrounded the garden and entered the garden's scenery which became a problem from the viewpoint of heritage garden preservation. Thereby, this study aimed to investigate the visual effect of external high-rise building views on the garden's scenery in visitors' perception. To achieve this aim, an in-situ survey was conducted among the visitors of Hama-rikyu Gardens by using a questionnaire with a range of questions to assess the external building sceneries. The results indicated that evaluation of the garden scenery as a whole was highly positive while the buildings in the garden sceneries were not liked, and they were perceived as disturbing. Furthermore, the negative effect of the buildings increased in the observation points where Shakkei (borrowed scenery) experience could be expected.
\end{abstract}

Keywords Japanese Garden, Daimyo Garden, Shakkei, Borrowed Scenery, High-rise Building, Landscape Preference

\section{Introduction}

According to Karl Marx economic infrastructure defines the social and cultural structure of the societies [1], parallel with this phenomenon, social infrastructure defines spatial organizations of the human environments like cities and towns. Despite the artificial landscape character of the urban and town landscapes, humans always need some natural elements in these artificial landscapes [2]. Thus, gardens and open green areas have been built in the cities and towns all around the globe according to the local conditions as well as social infrastructure. In Japan too, the cultural background of the country along with the effect of several social and economic changes in the history has shaped its landscapes. Although the phenomena of capitalist modernism have caused the mega-cities like Tokyo to become similar to each other, it is still possible to trace the unique identities of those by investigating the cultural heritage.

Taking Tokyo as a case, in Edo period (1603-1868) of Japan, there was a deep interconnectedness of culture and nature, so that Edo city (today Tokyo) was carefully integrated into its local environment. It was organized with a strong centrifugal logic in relation to its natural surroundings and topography [3]. Therefore, Edo was a city of views; many streets were aligned to provide urban vistas of Mt. Fuji to the west, Mt. Tsukuba to the north, and scenic hills and river views around the city [4]. Likewise, the gardens in the city too took full advantage of the native landscape and terrain of Edo [5]. In this sense, the gardens of this period, so-called 'daimyo gardens' were created with a deep consideration of visual qualities. What made these gardens a new prototype was their design feature called kaiyu-shiki teien (strolling garden) and the technique of Shakkei (borrowed scenery) [6]. The strolling gardens were designed along a path that rings around the garden to enjoy consecutive views. Different vistas along the route were viewed from different observation points [7]. Besides, these gardens made use of distant sceneries like mountains and incorporated them into the garden scenery by the design technique of Shakkei. Space was composed pictorially according to principles of foreground, midground, and background, extending the limits of the garden visually and conceptually. Thereby, these gardens focused attention not only in internal features but also 
distant views with the Shakkei technique [8] that was improved in Edo period daimyo gardens to accentuate the importance of visual culture to the appreciation of nature in gardens [7]. Both natural features, such as mountains, hills and plains, rivers, the ocean, and human-made structures, such as temple gates and pagodas could be used in these gardens as borrowed scenery [9]. In this term, the attribute of Shakkei technique which is to include such distant sceneries -that are all superior to human nature- within the garden composition, falls in line with the philosophy of the aesthetic ideal called the sublime.

During Meiji period (1868-1912), Japan opened itself to the West and joined the ranks of the industrialized nations. The immediate influence of Western culture dramatically changed the urban landscape of Tokyo. When estates became surrounded by higher structures of the middle-ground landscape, to preserve Shakkei became difficult [7]. As a result of urbanization in recent decades, with various urban renewal and redevelopment projects, the land-use around the traditional gardens has changed, and an increasing number of high-rise buildings have settled down in the surroundings of these gardens. Daimyo Gardens of Edo era - which previously had background scenes of nature elements - have lost those scenes with the rapid change of cityscape in Tokyo. Since high-rise buildings have filled the air of the city, Daimyo Gardens had to replace their background views with those buildings. Regarding the issue, some studies have been done to analyze the visual impact of the visible surrounding buildings on traditional Japanese gardens, and the results have indicated that the visibility of external buildings have a negative impact on visual quality of the gardens and cause landscape destruction [10-15]. Besides, an empirical study has demonstrated that a majority number of the visitors of a traditional Japanese garden (Ritsurin Garden in Takamatsu city) judged the visible external buildings as causing a negative impact and they supported conservation actions for reducing the conspicuousness of the building views [12]. However, when the user interpretations about the traditional gardens in Tokyo city are searched in social media, it is possible to find a range of judgments on the surrounding building views, such as 'modern concept of Shakkei' or appreciation to the contrast between modern and traditional [16-19]. Furthermore, a master architect of Shiodome high-rise project (progressed from 1995 in the north to the west surroundings of Hama-rikyu Gardens in Tokyo) gave a comment in an advertisement as "we have a good view to the famous garden (Hama-rikyu Gardens). That is Shakkei!" [20] Although the usage of the Shakkei word is found to be abused or a huge mistake [20], this statement of the architect is considered to be revealing that the traditional values, practices or terms are being replaced by the flow of time and space.

These divergent visions among the stakeholders point to the enduring discussion in the philosophy of aesthetics which is whether the beauty is 'in the object' or 'in the eyes of the beholder' [21]. Taking the visual effect of high-rise buildings on garden sceneries as an example, although the studies with objectivist approach have found striking results about the negative effect of the external buildings on the garden sceneries, laypersons' perceptions and preferences can differ according to their subjective qualities. In this sense, on the one hand, high-rise building views from a traditional garden can be seen as a symbol of damaged modernity and those buildings can be judged by causing a devaluation in the original spirit of the gardens. On the other hand, as Dupre [22] says, their daring heights may excite the mind and heart, and such feelings towards the modern buildings remind the concept of the sublime. In today's modern cities, people may have a tendency of being awed by the scale and power of such human creations, rather than nature's [23].

In this context, traditional daimyo gardens in Tokyo are considered to be good examples to display the shifting culture due to the modernization and urbanization phenomena which are shaped by capitalism. By the drastic change in the scenery of these gardens, the idea of Shakkei and the Sublime has altered from sheer nature such as Mt. Fuji, Mt. Tsukuba, rivers and the ocean into the human-made super high-rise buildings. Today, the landscape of Tokyo is visible by bird's eye view from the windows of the high-rise buildings and these buildings got the biggest opportunity by having a view to the beautiful traditional gardens from their windows which is both an aesthetic pleasure as well as an indispensable feature which increases the value of the land. On the other hand, the question of how observers assess the scenic value of these gardens from inside the gardens remains.

In the field of environmental aesthetics, a significant amount of research has been carried out to ensure that the 'human power' is applied properly, and people live peacefully in their environments [24]. Although the findings of these studies are various [25,26], the fact that people have strong preferences for the natural landscapes over built environments is a decisive finding [27-29]. However, the management of the green areas which have been diminishing in today's rapidly urbanized cities has become even a greater issue. Regarding traditional gardens in the cities, in order to maintain the landscape aesthetics, appropriate protection of the external landscape is as important as the protection of the inner landscape of the gardens [14]. But, to achieve sustainable environments is only possible by the participation of stakeholders. Although aesthetics seems to be a matter of taste varying from person to person, many studies pointed to the presence of commonalities in aesthetic preference and showed that aesthetics could be quantified [30]. Therefore, environmental aesthetics and sociological studies in parallel provide scientific results which are shaped by the participation of stakeholders which in turn meets the needs of today's democratic societies.

The previous studies about the visual impact of the high-rise building views on the traditional Japanese gardens dealt with the issue with the objective approach 
[10,11,13- 15], but the studies gauging visitor's preference is limited [12]. In this regard, this research was conducted to understand the garden visitors' perception and convey those indices to the experts to gain a better understanding of visitor preferences. In this study, the attitude of the respondents was measured by using the psychophysical model [31] of landscape aesthetics in which a limited number of studies have been conducted.

As aforementioned, it is observed that there is a conflict between different stakeholders on whether the surrounding high-rise buildings devalue the scenery of the traditional gardens or the contrast between the high-rise buildings and the garden is found to be attractive. Thereby, this research aims to reveal the attitude of visitors towards surrounding high-rise building sceneries from inside a traditional Japanese garden by an in-situ survey. In accordance with this aim, the objectives of this study may be classified as: to examine the attitudes towards external high-rise building views according to the physical attributes of the observation points and scenes, to determine the effect of external high-rise building views on the liking degree of the scenes (to like/dislike the scene), to reveal the relationships (differences and correlations) between the variables about the external high-rise building views, to reveal the effect of the visitors' socio-demographic background on the attitudes towards external high-rise building views.

\section{Materials and Methods}

An in-situ survey was conducted for the assessment of visitors. Eight sites in a traditional Japanese garden located in central Tokyo were selected for experiment.

\subsection{Study Area}

Hama-rikyu Gardens which is located in Chuo Ward of Tokyo Metropolitan City, Japan is selected as the study area (Figure 1). Hama-rikyu is a grand-scale stroll type (kaiyu-shiki teien) daimyo garden which reflects the characteristics of the Edo period gardens $[5,13]$. Due to its historical and cultural value, the garden was declared as a Special Place of Scenic Beauty and the Special Historic Site in 1952 by the Cultural Properties Protection Law of
Japan and today it is managed by Tokyo Metropolitan Park Association [32]. Although the garden itself is managed well and the elements of the garden preserved respectfully, the urbanization which has been occurred in the surroundings has caused some of the features of the garden's original design to be lost. This loss has occurred in distant sceneries that Hama-rikyu once made use of with the Shakkei technique (borrowed scenery) [33]. With the emergence of high-rise buildings, those distant sceneries such as Mt. Fuji, Mt. Tsukuba, Tokyo Bay, Boso Peninsula and Shinagawa Bay have been disappeared [32,34]. According to Shinji et al. [10], the impact of the high-rise buildings caused landscape destruction in Hama-rikyu Gardens, and this garden was found to be the one in which the building impact was the highest [10]. However, no studies have been done regarding the visitor opinions on this issue. Today, the location of this area lets the visitors watch the modern skyline of Tokyo while being in a heritage garden. Therefore, this garden is found to be a critical space where the perceptions about modern building views from inside a traditional garden can be investigated and discussed.

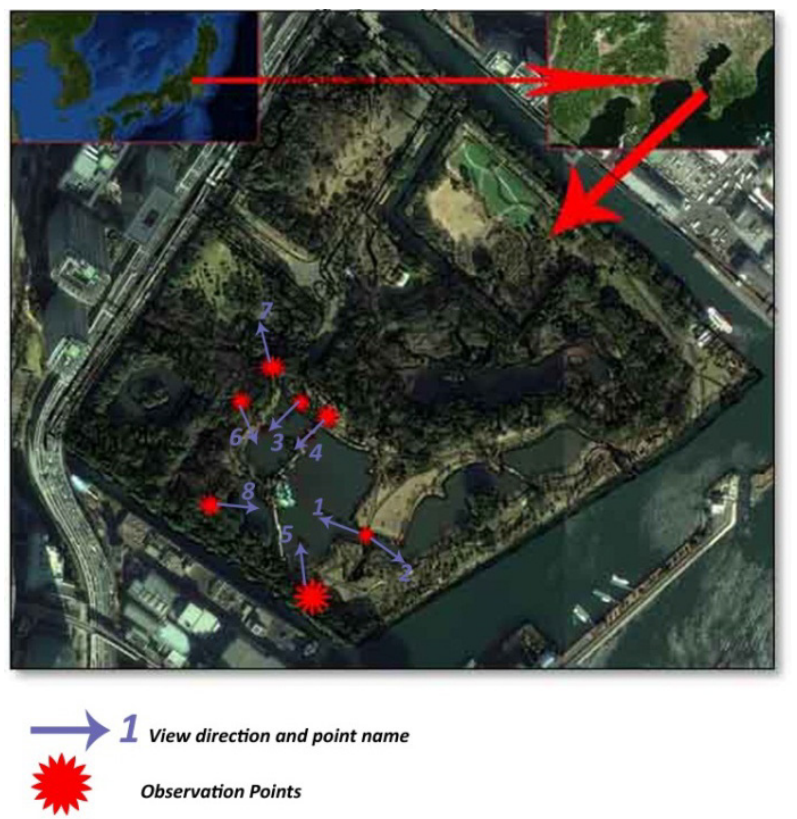

(Source: Developed from Yandex Maps. December 24, 2017).

Figure 1. The location of study area 


\subsection{Selected Observation Points}

Table 1. Observation points and their sceneries in categories

\begin{tabular}{|c|c|c|c|}
\hline \multicolumn{2}{|c|}{ (1) Open view - Unprotected observation point } & \multicolumn{2}{c|}{ (2) Closed view - Unprotected observation point } \\
\hline High-level Building Density & Low-level Building Density & High-level Building Density & \multicolumn{2}{c|}{ Low-level Building Density } \\
\hline 1. Nakanohashi Bridge-1 & 2. Nakanobashi Bridge-2 & $\begin{array}{c}\text { 3. In front of Wisteria trellis part } \\
\text { of Otsutaibashi Bridge }\end{array}$ & $\begin{array}{c}\text { 4. Next to Tsubame-no-ochaya } \\
\text { teahouse }\end{array}$ \\
\hline & & & \\
\hline (3) Open view - Protected observation point & Low-level Building Density & High-level Building Density & Low-level Building Density \\
\hline High-level Building Density & 7. Sangenbashi Bridge & 8. The forest surrounding Dai-sensui \\
pond
\end{tabular}

For the selection of the sites in the study area, firstly 36 sceneries from different sites in the garden were photographed by a DSLR camera (EF-S18-55 mm, f 3,5-5,6 lens). All the photos were taken with wide angle and as possible as open focus $(18 \mathrm{~mm}$. focal length and focus of photos vary between f 6-8). Secondly, all the photos were split into four categories which were used by Nasar et al. [35]. These categories are: (1) open view/unprotected observation point; (2) closed view/unprotected observation point; (3) open view/protected observation point; (4) closed view/protected observation point. Thirdly, the ratio of visible external buildings from each site was measured by a computer-aided design and drafting software application (AutoCAD 2017). This measurement was done by drawing the borders of the external buildings until achieving a closed shape so that the ratio of the buildings/entire scenery in each scenery could be measured. It was followed by the process of calculating the average building density for each category. Accordingly, the sceneries having higher building ratios than the average were taken as 'high-level building density' and the ones having lower building ratios than the average were taken as 'low-level building density.' Lastly, two sites per each category (one site: high-level building density; one site: low-level building density), eight sites in total were selected to be examined (Table 1).

\subsection{Procedure, Respondents and Questionnaire}

The survey was conducted on a clear day of August (12.08.2017). Respondents were selected from the garden visitors who were passing by the observation points.
Visitors who agreed to participate in the survey were asked to stand at a specific point at each observation point and look at the direction which was pointed with an arrow sign to fill out the questionnaire. Each respondent was stopped one at a time at the observation points.

129 (70 male, 59 female) visitors (between 15-18 per site) voluntarily took part in the study. $90 \%$ of the visitors who were approached agreed to participate. There were 65 Japanese and 64 foreign people visiting Tokyo from different countries who assessed the scenery. The age of respondents ranged from 12 to 76 .

Respondents rated each variable on a 5-point Likert scale. In the questionnaire, the first question -how much the subject liked the whole scene- was asked to embody predictors of building influence. This question was followed by a variety of statements to measure the perceived building influence. It had participants rate the degree to which:

I liked the buildings in the background of the garden scene (Not at all - Very much)

The buildings in the background of the garden scene are (Very disturbing - Very pleasant)

The buildings I see from this point should be lower in height (Strongly disagree - Strongly agree)

The color of the buildings I see from this point should be changed (Strongly disagree - Strongly agree)

I feel a deep contrast between the buildings in the background and the garden (Strongly disagree - Strongly agree)

The buildings in the background of the scene are sublime elements (Strongly disagree - Strongly agree)

The buildings in the background are an important part of 
the garden scenery (Strongly disagree - Strongly agree)

Additionally, socio-demographic attributes (gender, age, income, nationality, education level, whether the occupation is related to design disciplines or not and if any graduate level classes about natural environmental studies were taken) were noted.

\section{Results}

\subsection{Participant Features}

Before explaining the correlations between socio-demographic variables and the propositions about background buildings, it would be useful to describe the socio-demographic background of the respondents. Table 2 shows the frequency distribution of respondents' socio-demographic background.
When the table was examined, it was seen that $46 \%$ $(\mathrm{N}=59)$ of respondents were female and $54 \%(\mathrm{~N}=70)$ was male. All the respondents indicated their actual age in the survey and the data was classified under four different age group. In the questionnaire, the income level was also asked. However, $48 \%$ of the respondents did not answer this question. The respondents who indicated their income $(52 \%)$ was classified into four groups. The education level of the respondents was divided into six groups ranging from elementary school to $\mathrm{Ph}$.D. Nationality was classified into two groups as Japanese $(\mathrm{N}=65)$ and foreigners $(\mathrm{N}=64)$. Additionally, the respondents were asked whether their occupation is related to a design discipline or not, and whether they have taken any classes about the natural environment in a graduate-level program or not. The data showed that $22 \%$ of the respondents' occupation was related to a design discipline and $12 \%$ of the respondents have taken classes about the natural environment.

Table 2. Socio-demographic background of the respondents

\begin{tabular}{|c|c|c|c|c|c|c|}
\hline Gender & Female & Male & & & & \\
\hline $\mathrm{N}$ & 59 & 70 & & & & \\
\hline$\%$ & 45,7 & 54,3 & & & & \\
\hline Age & Under 23 & $23-40$ & $41-60$ & \multicolumn{2}{|c|}{61 and above } & \\
\hline $\mathrm{N}$ & 20 & 65 & 38 & 6 & & \\
\hline$\%$ & 15,5 & 50,4 & 29,5 & 4,7 & & \\
\hline Income & $0 \$$ & $1-4884 \$$ & $4885-26638 \$$ & $\begin{array}{l}\text { Above } \\
26639 \$\end{array}$ & Missing & \\
\hline $\mathrm{N}$ & 3 & 21 & 21 & 22 & 62 & \\
\hline$\%$ & 2,3 & 16,3 & 16,3 & 17,1 & 48,1 & \\
\hline Education & Elementary & $\begin{array}{l}\text { Junior-high } \\
\text { school }\end{array}$ & High-school & Bachelor & Master & Ph.D. \\
\hline $\mathrm{N}$ & 1 & 5 & 23 & 79 & 16 & 5 \\
\hline$\%$ & 0,8 & 3,9 & 17,8 & 61,2 & 12,4 & 3,9 \\
\hline Nationality & Japanese & Foreign & & & & \\
\hline $\mathrm{N}$ & 65 & 64 & & & & \\
\hline$\%$ & 50,4 & 49,6 & & & & \\
\hline
\end{tabular}

Table 3. Frequency and mean scores of the general attitude towards the propositions about background buildings

\begin{tabular}{|c|c|c|c|c|c|c|c|}
\hline & & Very Dis. & $\begin{array}{l}\text { Fairly } \\
\text { Dis. }\end{array}$ & Neutral & $\begin{array}{l}\text { Fairly } \\
\text { Plea. }\end{array}$ & Very Plea. & mean \\
\hline \multirow{3}{*}{ The buildings in the background of garden scene are } & $\mathrm{N}$ & 10 & 27 & 36 & 42 & 14 & \multirow[t]{2}{*}{3,18} \\
\hline & $\%$ & 7,8 & 20,9 & 27,9 & 32,6 & 10,9 & \\
\hline & & Not at all & a little & somewhat & Quite bit & Very Much & Mean \\
\hline \multirow{3}{*}{ I like the buildings in the background of the garden scene } & $\mathrm{N}$ & 17 & 34 & 34 & 27 & 17 & \multirow[t]{2}{*}{2,95} \\
\hline & $\%$ & 13,2 & 26,4 & 26,4 & 20,9 & 13,2 & \\
\hline & & $\begin{array}{l}\text { Strongly } \\
\text { Disagree } \\
\end{array}$ & Disagree & Neutral & Agree & $\begin{array}{l}\text { Strongly } \\
\text { Agree }\end{array}$ & Mean \\
\hline \multirow{2}{*}{$\begin{array}{l}\text { The buildings I see from this point in the background } \\
\text { should be lower in height }\end{array}$} & $\mathrm{N}$ & 8 & 24 & 41 & 28 & 28 & \multirow{2}{*}{3,34} \\
\hline & $\%$ & 6,2 & 18,6 & 31,8 & 21,7 & 21,7 & \\
\hline \multirow{2}{*}{$\begin{array}{l}\text { The color of the buildings I see from this point in the } \\
\text { background should be changed }\end{array}$} & $\mathrm{N}$ & 9 & 47 & 41 & 19 & 13 & \multirow{2}{*}{2,84} \\
\hline & $\%$ & 7,0 & 36,4 & 31,8 & 14,7 & 10,1 & \\
\hline \multirow{2}{*}{$\begin{array}{l}\text { I feel a deep contrast between the buildings in the } \\
\text { background and the garden }\end{array}$} & $\mathrm{N}$ & 1 & 15 & 24 & 56 & 33 & \multirow{2}{*}{3,81} \\
\hline & $\%$ & 0,8 & 11,6 & 18,6 & 43,4 & 25,6 & \\
\hline \multirow{2}{*}{$\begin{array}{c}\text { The buildings in the background of the scene are sublime } \\
\text { element }\end{array}$} & $\mathrm{N}$ & 14 & 23 & 47 & 40 & 5 & \multirow{2}{*}{2,99} \\
\hline & $\%$ & 10,9 & 17,8 & 36,4 & 31,0 & 3,9 & \\
\hline \multirow{2}{*}{$\begin{array}{c}\text { The buildings in the background are an important part of } \\
\text { the garden scenery }\end{array}$} & $\mathrm{N}$ & 17 & 25 & 25 & 48 & 14 & \multirow{2}{*}{3,13} \\
\hline & $\%$ & 13,2 & 19,4 & 19,4 & 37,2 & 10,9 & \\
\hline
\end{tabular}


Table 3 shows the frequency and mean scores of the general attitude towards the propositions about background buildings. Regarding Table 3, the majority of the respondents $(32,6 \%)$ indicated that the background buildings were fairly pleasant. On the other hand, the mean score of liking degree of the buildings was quite low $(2,95)$.

Although $31,8 \%$ of the respondents $(\mathrm{N}=41)$ had a neutral attitude towards the proposition of 'the buildings should be lower in height', the total number of respondents who agreed $(\mathrm{N}=28,21,7 \%)$ and strongly agreed $(\mathrm{N}=28,21,7 \%)$ with this proposition were the majority. On the other hand, the majority of the respondents $(\mathrm{N}=47,36,4 \%)$ disagreed with the proposition of 'the color of the background buildings should be changed.' The majority $(\mathrm{N}=56$, $43,4 \%$-agree; $N=33,25,6 \%$-strongly agree) agreed with the proposition of 'I feel a deep contrast between the buildings and the garden.' Most of the respondents (36.4\%) were neutral towards the proposition of 'the background buildings are the sublime element.' Lastly, the majority $(\mathrm{N}=48,37,2 \%)$ agreed that 'the background buildings are an important part of the garden scenery.'

\subsection{Attitudes towards External High-Rise Building Views According to the Observation Points and Scenes}

Firstly, the relationships between the variables about external buildings and the physical attributes of the scenes/observation points were analyzed. As mentioned previously in the material-method section, there were eight different observation points in which visitor inputs were gained. The analysis results showed that perceived pleasantness/disturbance from the background buildings $(\mathrm{F}=0,816 \mathrm{df}=7-121 \mathrm{p}>0,5) \quad$ or to like/dislike the background buildings $(\mathrm{F}=0,628 \mathrm{df}=7-121 \mathrm{p}>0,5)$ was not related to the attributes of the observation points or the scenes. The only proposition which differed according to the observation points was 'I feel a deep contrast between the garden and background buildings' $(\mathrm{F}=2,110 \mathrm{df}=7-121$ $\mathrm{p}<0,05$ ). In this sense, the feeling of contrast was the highest in 'Nakanobashi Bridge-2' $(4,38)$ while the lowest level of contrast was felt in the point named 'the forest area surrounding Dai-sensui' $(3,33)$. Besides, the rate of the same proposition (I feel a deep contrast between the garden and background buildings) significantly differed according to the type of observation points (open, closed, protected, unprotected). It was seen that contrast was felt more in open views $(4,03)$ than in the closed ones $(3,59)$ $(\mathrm{F}=6,779 \mathrm{df}=1-127 \mathrm{p} \leq 0,01)$, and contrast was felt more in unprotected points $(4,03)$ than in the protected points $(3,6)$ $(\mathrm{F}=6,592 \mathrm{df}=1-127 \mathrm{p}<0,05)$.

On the other hand, when the correlation between the variables about the buildings and the measured building ratio was investigated, it was seen that there was no variable which had a significant correlation with building ratio in a scene (perceived disturbance/pleasantness $\mathrm{r}=0,010 \mathrm{p}>0,5$; liking degree of the background buildings $\mathrm{r}=0,050 \mathrm{p}>0,5$; buildings should be lower in height $\mathrm{r}=0,019$ $\mathrm{p}>0,5$; color should change $\mathrm{r}=-0,040 \mathrm{p}>0,5$, contrast $r=0,160 p>0,05$, sublime element $r=0,092 p>0,1$; important part of the scenery $r=0,097 \mathrm{p}>0,1)$.

\subsection{The Effect of External High-Rise Building Views on the Liking Degree of the Scenes}

Bivariate correlation test results showed that there was no significant correlation between building ratio and the liking degree of the scenes (to like/dislike the scenery) $(\mathrm{r}=0,128 \mathrm{p}>0,05)$. But, there was a significant correlation between perceived pleasantness/disturbance from the buildings and the liking degree of the scenes $(r=0,246$ $\mathrm{p} \leq 0,005$ ). It meant that the visitors who assessed the buildings as pleasant liked the whole scene more compared to the visitors who assessed the buildings disturbing.

Furthermore, the variable which is 'I feel a deep contrast between the garden and the buildings' was found to be having a significant correlation with the liking degree of the scenes $(r=0,217 p<0,05)$. This finding suggested that if one felt a deep contrast between the garden and the buildings, his/her liking degree of the scene was higher than of the one who does not feel any contrast. The rest of the variables were not significantly correlated with the liking degree of the scenes (to like/dislike the buildings $\mathrm{r}=0,162 \mathrm{p}>0,05$; buildings should be lower in height $\mathrm{r}=-0,029 \mathrm{p}>0,5$; color of the buildings should be changed $r=-0,148 p>0,05$; buildings are sublime element $r=0,066$ $p>0,05$; buildings are an important part of the scenery $r=0,139 p>0,05)$ (Table 4).

Table 4. Correlations with the liking degree of the scenes

\begin{tabular}{|c|c|c|c|c|c|c|c|c|}
\hline & & $\begin{array}{l}\text { The buildings } \\
\text { in the } \\
\text { background of } \\
\text { the garden } \\
\text { scene are (very } \\
\text { disturbing - } \\
\text { Very pleasant) }\end{array}$ & $\begin{array}{l}\text { I like the } \\
\text { buildings in } \\
\text { the } \\
\text { background of } \\
\text { the garden } \\
\text { scene }\end{array}$ & $\begin{array}{l}\text { The buildings } \\
\text { I see from this } \\
\text { point in the } \\
\text { background } \\
\text { should be } \\
\text { lower in height }\end{array}$ & $\begin{array}{l}\text { The color of } \\
\text { the buildings I } \\
\text { see from this } \\
\text { point in the } \\
\text { background } \\
\text { should be } \\
\text { changed }\end{array}$ & $\begin{array}{l}\text { I feel a deep } \\
\text { contrast } \\
\text { between the } \\
\text { buildings in } \\
\text { the } \\
\text { background } \\
\text { and the garden }\end{array}$ & $\begin{array}{l}\text { The buildings } \\
\text { in the } \\
\text { background of } \\
\text { the scene are } \\
\text { sublime } \\
\text { element }\end{array}$ & $\begin{array}{l}\text { The buildings } \\
\text { in the } \\
\text { background } \\
\text { are an } \\
\text { important part } \\
\text { of the garden } \\
\text { scenery }\end{array}$ \\
\hline \multirow{2}{*}{$\begin{array}{l}\text { I liked the } \\
\text { scene from } \\
\text { this point }\end{array}$} & $\begin{array}{c}\text { Pearson } \\
\text { Correlation }\end{array}$ &, $246^{* *}$ & ,162 &,- 029 &,- 148 &, $217^{*}$ & ,066 & ,139 \\
\hline & $\begin{array}{c}\text { Sig. } \\
\text { (2-tailed) }\end{array}$ & ,005 & ,067 & ,740 & ,095 & ,014 & ,455 & ,118 \\
\hline
\end{tabular}




\subsection{Variance between the Variables of the External High-Rise Buildings and the Liking Degree of the Scenes}

When the differences between variables were examined, the variance test showed that there was no significant difference between perceived pleasantness/disturbance from the background buildings $(3,18)$ and the liking degree of the background buildings $(2,95)(\mathrm{F}=2,498 \mathrm{df}=1-256$ $\mathrm{p}>0,1)$. However, the variance test revealed a significant inconsistency between the liking degree of the scenes $(3,78)$ and the liking degree of the background buildings $(2,95)$ $(\mathrm{F}=35,882, \mathrm{df}=1-256 \mathrm{p}<0,001)$. When the mean scores of the variables were investigated, the variable for the liking degree of the scene was found to be significantly higher than the liking degree of the background buildings. This situation implied that while respondents liked the general scenery as a whole, they disliked the buildings in the background.

When this difference was examined for each observation point, five of the observation points among eight showed a significant difference between the liking degree of the scene and the liking degree of the background buildings (Nakanohashi Bridge-1 - the liking degree of the scene: 3,94 , liking degree of the buildings: $3,12, \mathrm{~F}=4,847 \mathrm{df}=1-30$ $\mathrm{p}<0,05$. Nakanohashi Bridge- 2 - the liking degree of the scene: 3,94; liking degree of the buildings: 2,56, $\mathrm{F}=11,672$ $\mathrm{df}=1-30 \mathrm{p}<0,005$. Mt. Fujimi - the liking degree of the scene: 4,2 , liking degree of the buildings: $2,87, F=18,543$ $\mathrm{df}=1-28 \mathrm{p}<0,001$. Mt. Hakkei - the liking degree of the scene: 4,0 , liking degree of the buildings: $2,83, \mathrm{~F}=8,248$ $\mathrm{df}=1-34 \mathrm{p}<0,01$. Next to Tsubame-no-ochaya teahouse liking degree the scene: 3,71 , liking degree of the buildings: $2,71, \mathrm{~F}=4,313 \mathrm{df}=1-32 \mathrm{p}<0,05)$. Furthermore, there was a significant difference between the liking degree of the scene $(3,78)$ and perceived pleasantness/disturbance $(3,18)$ from the background buildings $(\mathrm{F}=21,047 \mathrm{df}=1-256$ $\mathrm{p}<0,001)$. Once again, the same five points showed a significant difference between these two variables (Nakanohashi-1 - liking degree the scene: 3,94, pleasantness/disturbance of the buildings: $3,12, \mathrm{~F}=5,163$ $\mathrm{df}=1-30 \mathrm{p}<0,05$. Nakanohashi Bridge- 2 - the liking degree of the scene: 3,94, pleasantness/disturbance of the buildings: $2,94, \mathrm{~F}=6,690 \mathrm{df}=1-30 \mathrm{p}<0,05$. Mt. Fujimi - the liking degree of the scene: 4,2 , pleasantness/disturbance of the buildings: $3,47, \mathrm{~F}=4,680 \mathrm{df}=1-28 \mathrm{p}<0,05$. Mt. Hakkei the liking degree of the scene: 4,0, pleasantness/disturbance of the buildings: $3,11, \mathrm{~F}=6,078$ $\mathrm{df}=1-34 \mathrm{p}<0,05$. Next to Tsubame-no-ochaya teahouse the liking degree of the scene: 3,71, pleasantness/disturbance of the buildings: $2,76, \mathrm{~F}=4,258$ $\mathrm{df}=1-32 \mathrm{p}<0,05)$. The analysis results showed that the highest difference between the mean scores of the liking degree of the scene and liking degree of the buildings/perceived pleasantness-disturbance from the buildings was seen in the observation points namely Mt. Fujimi and Mt. Hakkei which are both artificial hills in the garden.

\subsection{Attitudes towards External High-Rise Building Views According to the Socio-demographic Background of the Respondents}

Correlation analysis was performed to reveal the relationships between socio-demographic variables and the propositions about external buildings (Table 5). According to the analysis results, socio-demographic variables had a significant effect on different propositions.

The results of this analysis showed that education level was a significant independent variable on perceived pleasantness/disturbance from the background buildings $(r=0,184 p<0,05)$. Based on the result, the respondents who have the highest education level assessed the background buildings as being more pleasant compared to the assessment of the respondents who have a lower level of education.

Gender was found to be a significant variable on the proposition of 'In the future, the buildings I see from this point in the background should be lower in height' $(r=-0,182 p<0,05$. Females were coded as " 1 ", males were coded as "2"). It was observed that the female respondents had a higher agreement on this proposition compared to the male respondents.

Income was found to be the significant variable on the proposition of "In the future, the color of the buildings I see from this point in the background should be changed" $(\mathrm{r}=0,262 \mathrm{p}<0,05)$. Based on this finding, it was seen that respondents who have higher income level agreed with this proposition.

Nationality was found to be the variable which significantly correlated with the proposition of "I feel a deep contrast between the buildings in the background and the garden" ( $\mathrm{r}=0,254 \mathrm{p}<0,005$, Japanese respondents were coded as " 1 "; Foreign respondents were coded as " 2 "). It was seen that foreign respondents felt significantly more contrast between the garden and the background buildings than the Japanese respondents did.

Age was found to be a significant factor on the propositions of "The buildings in the background of the scene are a sublime element" $(\mathrm{r}=-0,217 \mathrm{p}<0,05)$ and "The buildings in the background are an important part of the garden scenery" $(\mathrm{r}=-0,203 \mathrm{p}<0,05)$. The older respondents showed a significant disagreement with these statements.

\subsection{The Variables Related to the Liking Degree of the External Buildings}

An intriguing finding of correlation test above was that the none of the socio-demographic variables had a significant effect on the liking degree of the background buildings (Gender $r=0,111 p>0,05$, Age $r=-0,132 p>0,05$, Income $r=-0,020 p>0,5$, Education $r=0,065 p>0,05$ and Nationality $r=0,081 \mathrm{p}>0,05$ ) (Table 5). Therefore, linear multiple regression analysis has been done to reveal the variables which were significantly effective on liking degree of background buildings (Table 6). 
Table 5. Correlations between socio-demographic variables and propositions

\begin{tabular}{|c|c|c|c|c|c|c|c|c|}
\hline & & Gender & Age & Income & Education & Nationality & Occupation & Nat.cl \\
\hline $\begin{array}{l}\text { The buildings in the background of garden } \\
\text { scene are (Very disturbing-Very pleasing) }\end{array}$ & $\begin{array}{l}\text { Pear. } \\
\text { Cor. }\end{array}$ & $-0,021$ & 0,045 & $-0,085$ & $0,184^{*}$ & 0,064 & $-0,053$ & 0,050 \\
\hline \multirow{2}{*}{$\begin{array}{l}\text { I like the buildings in the background of the } \\
\text { garden scene }\end{array}$} & $\begin{array}{l}\text { Pear. } \\
\text { Cor. }\end{array}$ & 0,111 & $-0,132$ & $-0,020$ & 0,065 & 0,081 & $-0,127$ & 0,114 \\
\hline & Sig. & 0,211 & 0,136 & 0,871 & 0,467 & 0,360 & 0,152 & 0,199 \\
\hline \multirow{2}{*}{$\begin{array}{l}\text { The buildings I see from this point in the } \\
\text { background should be lower in height }\end{array}$} & $\begin{array}{l}\text { Pear. } \\
\text { Cor. }\end{array}$ & $-0,182^{*}$ & 0,067 & 0,023 & $-0,092$ & $-0,155$ & 0,080 & $-0,023$ \\
\hline & Sig. & 0,039 & 0,451 & 0,852 & 0,299 & 0,080 & 0,367 & 0,798 \\
\hline \multirow{2}{*}{$\begin{array}{l}\text { The color of the buildings I see from this } \\
\text { point in the background should be changed }\end{array}$} & $\begin{array}{l}\text { Pear. } \\
\text { Cor. }\end{array}$ & $-0,060$ & 0,124 & $0,262^{*}$ & $-0,127$ & $-0,159$ & 0,026 & $-0,127$ \\
\hline & Sig. & 0,502 & 0,161 & 0,032 & 0,152 & 0,072 & 0,773 & 0,152 \\
\hline $\begin{array}{l}\text { I feel a deep contrast between the buildings } \\
\text { in the background and the garden }\end{array}$ & Sig. & 0,591 & 0,243 & 0,710 & 0,595 & 0,004 & 0,575 & 0,178 \\
\hline \multirow{2}{*}{$\begin{array}{l}\text { The buildings in the background of the } \\
\text { scene are sublime element }\end{array}$} & $\begin{array}{l}\text { Pear. } \\
\text { Cor. }\end{array}$ & 0,038 & $-0,217^{*}$ & $-0,050$ & $-0,037$ & 0,067 & 0,004 & 0,073 \\
\hline & Sig. & 0,668 & 0,014 & 0,687 & 0,677 & 0,450 & 0,964 & 0,414 \\
\hline \multirow{2}{*}{$\begin{array}{l}\text { The buildings in the background are an } \\
\text { important part of the garden scenery }\end{array}$} & $\begin{array}{l}\text { Pear. } \\
\text { Cor. }\end{array}$ & 0,073 & $-0,203^{*}$ & $-0,047$ & 0,064 & 0,121 & $-0,028$ & 0,079 \\
\hline & Sig. & 0,410 & 0,021 & 0,706 & 0,472 & 0,173 & 0,757 & 0,372 \\
\hline
\end{tabular}

**. Cor. is significant at the 0.01 level (2-tailed)., *. Cor. is significant at the 0.05 level (2-tailed).

Table 6. Multiple regression analysis of the propositions about background buildings and socio-demographic variables

\begin{tabular}{|c|c|c|c|c|c|c|c|}
\hline \multicolumn{8}{|c|}{ Regression Model } \\
\hline \multirow{2}{*}{ Model } & \multicolumn{2}{|c|}{$\begin{array}{l}\text { Unstandardized } \\
\text { Coefficients }\end{array}$} & \multirow{2}{*}{$\mathrm{t}$} & \multirow{2}{*}{ Sig. } & \multicolumn{3}{|c|}{ Correlations } \\
\hline & $\mathrm{B}$ & Std. Error & & & Zero-order & Partial & Part \\
\hline (Constant) & 0,967 & 1,456 & 0,664 & 0,509 & & & \\
\hline Gender $($ Dummy variate Female $=1$ ) & 0,153 & 0,270 & 0,567 & 0,573 &,- 0067 & 0,077 & 0,052 \\
\hline Age & 0,001 & 0,012 & 0,125 & 0,901 & $-0,161$ & 0,017 & 0,012 \\
\hline Income & 1,794 & 0,000 & 0,347 & 0,730 & $-0,020$ & 0,047 & 0,032 \\
\hline Education & 0,210 & 0,199 & 1,057 & 0,295 & 0,176 & 0,142 & 0,098 \\
\hline Nationality (Dummy variate Japanese=1) & 0,121 & 0,334 & 0,363 & 0,718 & 0,008 & 0,049 & 0,034 \\
\hline Occupation (Dummy variate Designer=1) & $-0,497$ & 0,309 & $-1,609$ & 0,114 & $-0,091$ & $-0,214$ & $-0,149$ \\
\hline Nature class (Dummy variate Nature Class taken=1) & 0,441 & 0,442 & 0,997 & 0,323 & 0,205 & 0,134 & 0,092 \\
\hline $\begin{array}{l}\text { The buildings I see from this point in the background should be } \\
\text { lower in height }\end{array}$ & $-0,237$ & 0,139 & $-1,703$ & 0,094 & $-0,513$ & $-0,226$ & $-0,157$ \\
\hline $\begin{array}{l}\text { In the future, the color of the buildings I see from this point in the } \\
\text { background should be changed }\end{array}$ & 0,053 & 0,127 & 0,420 & 0,676 & $-0,351$ & 0,057 & 0,039 \\
\hline $\begin{array}{l}\text { I feel a deep contrast between the buildings in the background and } \\
\text { the garden }\end{array}$ & $-0,149$ & 0,134 & $-1,110$ & 0,272 & $-0,112$ & $-0,149$ & $-0,103$ \\
\hline The buildings in the background of the scene are sublime element & 0,409 & 0,148 & 2,760 & $0,008 * *$ & 0,580 & 0,352 & 0,255 \\
\hline $\begin{array}{l}\text { The buildings in the background are an important part of the garden } \\
\text { scenery }\end{array}$ & 0,291 & 0,121 & 2,412 & $0,019 *$ & 0,591 & 0,312 & 0,223 \\
\hline
\end{tabular}


In this analysis, the propositions about the background buildings and socio-demographic variables (gender (Dummy variate female $=1$, male $=0$ ), age, education level, nationality (Dummy variate Japanese $=1$, foreign $=0$ ), whether the occupation is related to design disciplines or not (Dummy variate designer $=1$, non-designer $=0$ ), if any graduate level classes about natural environmental studies were taken (Dummy variate if taken=1, if not taken=0)) were examined.

When the results of multiple regression analysis were investigated, two attributes were found to be significantly effective on the liking degree of background buildings. These were the propositions of 'background buildings are a sublime element,' and 'background buildings are an important part of the garden scenery' (Table 6). Independent variables explained $53,9 \%$ of variance on liking degree of background buildings $(\mathrm{F}=5,260 \mathrm{df}=12-54$ $\mathrm{p}<0,001)$. The level of agreement on these propositions was found to be positive indicators of the dependent variable (liking degree of the buildings). Analysis results showed that, apart from these two, no other variable had a significant effect on the liking the degree of the background buildings.

\subsection{The Variables Related to the Perceived Pleasantness/Disturbance from the External Buildings}

Another linear multiple regression analysis was performed by taking perceived pleasantness/disturbance from the background buildings as a dependent variable (Table 7). In this analysis, same variables in Table 6 were used as independent variables. The results showed that there were two significantly effective variables on perceived pleasantness/disturbance from the background buildings. These were the agreement level with the propositions of 'I feel a deep contrast between the buildings in the background and the garden' and 'The buildings in the background are an important part of the garden scenery.' Independent variables explained 47,3\% of variance on perceived pleasantness/disturbance from the background buildings $(\mathrm{F}=4,039 \mathrm{df}=12-54 \mathrm{p}<0,001)$.

Table 7. Multiple regression analysis of socio-demographic variables and propositions on perceived pleasantness/disturbance from the background buildings

\begin{tabular}{|c|c|c|c|c|c|c|c|}
\hline \multicolumn{8}{|c|}{ Regression Model } \\
\hline \multirow{2}{*}{ Model } & \multicolumn{2}{|c|}{$\begin{array}{l}\text { Unstandardized } \\
\text { Coefficients }\end{array}$} & \multirow{2}{*}{$\mathrm{t}$} & \multirow{2}{*}{ Sig. } & \multicolumn{3}{|c|}{ Correlations } \\
\hline & B & Std. Error & & & Zero-order & Partial & Part \\
\hline (Constant) & 2,097 & 1,331 & 1,575 & 0,121 & & & \\
\hline Gender (Dummy variate Female=1) & 0,210 & 0,247 & 0,848 & 0,400 & 0,005 & 0,115 & 0,084 \\
\hline Age & 0,013 & 0,011 & 1,184 & 0,242 & $-0,052$ & 0,159 & 0,117 \\
\hline Income & $-1,510$ & 0,000 & $-0,319$ & 0,751 & $-0,085$ & $-0,043$ & $-0,032$ \\
\hline Education & 0,159 & 0,182 & 0,875 & 0,385 & 0,190 & 0,118 & 0,086 \\
\hline Nationality (Dummy variate Japanese $=1$ ) & $-0,095$ & 0,305 & $-0,311$ & 0,757 & 0,002 & $-0,042$ & $-0,031$ \\
\hline Occupation (Dummy variate Designer=1) & $-0,311$ & 0,282 & $-1,100$ & 0,276 & $-0,052$ & $-0,148$ & $-0,109$ \\
\hline Nature class (Dummy variate taken Nature Class $=1$ ) & 0,163 & 0,404 & 0,404 & 0,688 & 0,153 & 0,055 & 0,040 \\
\hline $\begin{array}{l}\text { The buildings I see from this point in the background should } \\
\text { be lower in height }\end{array}$ & $-0,114$ & 0,127 & $-0,897$ & 0,374 & $-0,378$ & $-0,121$ & $-0,089$ \\
\hline $\begin{array}{l}\text { The color of the buildings I see from this point in the } \\
\text { background should be changed }\end{array}$ & 0,033 & 0,116 & 0,284 & 0,778 & $-0,344$ & 0,039 & 0,028 \\
\hline $\begin{array}{l}\text { I feel a deep contrast between the buildings in the } \\
\text { background and the garden }\end{array}$ & $-0,375$ & 0,123 & $-3,055$ & $0,003 * *$ & $-0,326$ & $-0,384$ & $-0,302$ \\
\hline $\begin{array}{c}\text { The buildings in the background of the scene are sublime } \\
\text { element }\end{array}$ & 0,225 & 0,136 & 1,660 & 0,103 & 0,435 & 0,220 & 0,164 \\
\hline $\begin{array}{l}\text { The buildings in the background are an important part of the } \\
\text { garden scenery }\end{array}$ & 0,320 & 0,110 & 2,902 & $0,005^{* *}$ & 0,523 & 0,367 & 0,287 \\
\hline
\end{tabular}


The level of agreement on 'I feel a deep contrast between the buildings in the background and the garden' was found to be a negative indicator of perceived pleasantness/disturbance from the buildings, while 'The buildings in the background are an important part of the garden scenery" was a positive indicator.

\section{Discussion}

In this study, although eight different sceneries were selected to be examined, the stimuli may still have some limitations. Nevertheless, by focusing on some findings, some attitudes towards the high-rise building views which enter the garden scenery can be discussed.

The liking degree of the scenes (to like/dislike the scenery) had significant relationships with two variables. One of them was the perceived pleasantness/disturbance from the buildings. This finding indicated that the perceived disturbance from the background buildings affected the overall liking degree of the garden scenery in a negative way. This situation implies that, depending on the subjective qualities of the observer, the view of high-rise buildings may devalue the garden scenery or vice versa. Therefore, this finding emphasizes the effect of personal taste and experiences on the perception for the high-rise building views from inside the garden.

The other variable which was correlated with the liking degree of the scenes was 'to feel a deep contrast between the garden and the background buildings.' This finding indicated that the feeling of contrast affects the liking degree of a scene positively. Regarding this finding alone, this correlation could point out to the fact that visitors enjoy the sceneries which have a combination of traditional garden elements and modern urbanism. However, findings revealed that the feeling of contrast was significantly related to the physical qualities of the observation points/scenes. It was seen that this feeling was higher in the predefined open views and unprotected observation points compared to the closed views and protected observation points. Given that these points offer open sceneries with a wide panorama (open view) and that there is no obstacle in front of or around them (unprotected observation point), the observer encounters with a scenery in which both the garden and the buildings can be seen together without any obstacle. In this sense, the positive relationship between the feeling of contrast and the liking degree of the scenes can be interpreted in a way that the combination of modern and traditional is pleasurable. On the other hand, it has been revealed by some empirical research that openness (prospect) of a landscape setting is an effective indicator for landscape preferences and the points which offer open views are preferable [35-38]. In this case, to explain the correlation between the feeling of contrast and the liking degree of the scenes as an appreciation to the combination of modern and traditional can be insufficient since this relationship can be the reflection of prospect's strong effect on landscape preferences. Therefore, the observers might like the scenery because of its openness but might feel a contrast between the garden and the buildings at the same observation point once again due to the openness factor of the view. Additionally, the feeling of contrast was found not to be affected by the ratio of buildings in a scene. This situation may be explained in a way that whatever the ratio of the buildings is, when the buildings enter the garden scenery strikingly, the sense of contrast increases. Besides, the components that cause a feeling of contrast can be related to the characteristics of the buildings other than the ratio in a scene.

As an evidence of the negative effect of external buildings on the garden scenery, the regression analysis showed that there was an inverse proportion between the feeling of contrast and perceived pleasantness/disturbance from the buildings. This result implies that the feeling of contrast increases when the perceived disturbance from the buildings is high. And, this situation points out that the feeling of contrast occurs in a negative state of mind due to the disturbance of the buildings. Thus, this finding reinforces the likelihood that the positive correlation between the feeling of contrast and the liking degree of the scenes may be explained by the effect of prospect on landscape preferences.

The negative effect of the external buildings became clearer with the results of variance tests which showed the significant difference between the mean scores of the liking degree of the scenes and the mean scores of the liking degree of the buildings as well as the perceived pleasantness/disturbance from the buildings. This finding explains that the scenery of the garden was appreciated highly as a whole. On the other hand, the external buildings which enter those sceneries were not liked and found to be disturbing. When this difference investigated for each observation point, the most significant difference between the mean scores of liking degree of the buildings and the liking degree of the scenes, as well as perceived pleasantness/disturbance from the buildings and the liking degree of the scenes was found to be in the observation points namely Mt. Fujimi and Mt. Hakkei which are both artificial hills in the garden. From the top of these observation points, observers can enjoy a broad panorama including the landscape in the garden and its surroundings. It is known that from the top of these two artificial hills, one could experience the Shakkei (borrowed scenery) technique in the past since it was possible to have a distant view of Mt. Fujimi, Mt. Tsukuba, Edo Bay (Tokyo Bay) and the mountains of Boso Peninsula [34]. The results indicated that these two points were the most appreciated ones. On the other hand, the buildings which enter the sceneries of these points were not appreciated and even found to be more disturbing comparing to the other points. Thus, this condition may be a sign of the negative impact of the high-rise buildings on Shakkei technique and destruction in the garden's scenery as some authors $[10-15,32]$ indicated. Furthermore, this situation may 
imply that the sceneries which have been filled with high-rise building failed to satisfy the expectations of observers. However, the interpretation of this finding should be verified by a future experiment which may use simulations with a controlled view change.

Another important finding of this research was that the liking degree of the background buildings was not significantly related to the physical qualities of the observation points/sceneries (i.e., observation point categories and building ratio in a scene). Furthermore, there was no significant difference between the liking degree of the buildings and perceived pleasantness/disturbance from them. It is also noteworthy that, according to the regression analysis, the liking degree of the buildings was affected by only two variables (the buildings are an important part of the scenery, the buildings are the sublime element). All the results above point out to the fact that the liking degree of the buildings may be free from the objective characteristics of the space but mainly decided by the subjective characteristics of the observers. However, Stamps and Nasar [39] indicated that when the number of the stimuli is limited, the results may be determined by the subjective characteristics of the respondents rather than the physical characteristics of an environment. Thus, future research should investigate the components which may influence the liking degree of the buildings with more comprehensive stimuli.

When the effect of socio-demographic variables on the attitudes towards the buildings is examined, meaningful relationships can be conceived of striking results. For instance, the results showed that as the education level increased, the buildings were not perceived as disturbing and even found to be pleasing a little. This finding may be interpreted as the fact that high education level leads to a more tolerant view towards the conditions of modern society and urbanism. Therefore, those who hold a higher level of education may have a tendency of having positive appraisals towards the skyline of Tokyo metropolitan which can be the symbol of modern life. By selecting proper data samples and comprehensive attitude scales, further research in this regard may investigate this hypothesis and reveal its effective variables.

Another finding on the effect of socio-demographic attributes was that the female respondents significantly wanted the background buildings to be lower when it was compared with the attitude of the male respondents who were more neutral. However, to reveal the explanatory relationships of this finding could not be possible due to the insufficient data collection instruments. Thus, this attitude of the females should be investigated and explained with related reasons by conducting future exploratory surveys.

The results showed that the respondents with high-level income showed significant demand for a change in buildings' colors. On the other hand, considering that there was no meaningful relationship between the income and the proposition of 'the background buildings should be lower', the respondents who have high-income - perhaps with the Pollyanna effect- actually liked the buildings as they are, but thought that it could be good if their colors were changed. However, the fact that the majority of the respondents disagreed with the proposition of the color change shows that the regulations about the exterior building colors which is decided by Tokyo Metropolitan Landscape Plan [40] are effective in terms of obtaining a harmony.

One of the interesting findings of this study was that the foreign respondents had a significantly greater agreement with the proposition of 'I feel a deep contrast between the garden and the background buildings' than the Japanese respondents did. This situation may be a sign of the familiarity of Japanese respondents with the scenery so that they considered it a part of everyday life while foreign respondents found the same scenery odd.

The results showed that younger respondents perceived the buildings as an important part of the garden scenery and as a sublime element. In this regard, it can be deduced that the older age groups have a more negative view towards the buildings since they showed a significant disagreement on these statements. This situation may be explained by the fact that older age groups may have a traditional approach and that they may yearn for the old times. This finding was consistent with the research results of Arifin and Masuda [12] in which they found that the visitors above 20 years of age had a stronger desire for conservation action in a traditional garden while those under 20 years of age showed minimal awareness of the visual problems caused by surrounding buildings. However, more extensive studies can bring out supportive results or reject this finding.

\section{Conclusions}

This study had some limitations since it focused mainly on the relation between the garden and the external building views so that it did not collect the physical attributes of the buildings in detail. Therefore, it is advised that further studies on this issue should consider physical characteristics of the buildings with a deeper approach and gain more data about their formal aesthetic attributes and symbolic meanings. Nevertheless, despite limited data collection instruments and sampling, significant or non-significant relationships between variables may help to illustrate the effect of external buildings on the traditional garden.

For instance, the fact that no significant relationship was found between the measured physical variables (building ratio, characteristics of the observation points) and the liking degree of the buildings or perceived pleasantness/disturbance from the buildings may indicate that people's perceptions about the external buildings may be related to the subjective variables rather than objective features of the environment. However, to test this hypothesis, it is necessary to conduct more extensive 
studies with more stimuli. On the other hand, the findings of the variance test were striking in terms of indicating that the observers appreciate the garden scenery while they do not like the buildings which enter those sceneries. This finding reveals that the interior scenery of Hama-rikyu Gardens maintains its visual quality in the perception of observers. But, when it is thought that the background elements and distant landscapes should also be considered as a part of this traditional garden, the buildings at the background damage its overall scenery. Looking at the significant difference between the liking degree of the overall scenery and the liking degree of the buildings, the findings imply that the loss of Shakkei (borrowed scenery) which is caused by the external buildings affects the garden's scenery negatively in observer's perception. Another important finding of the study was that the feeling of contrast between the garden and the buildings was in significant correlation with the variables of perceived disturbance/pleasantness from the buildings and the liking degree of the buildings. This finding implies that the feeling of contrast may be attractive at first glance, but as the feeling of contrast increases the level of perceived disturbance from the buildings increases as well. Furthermore, the majority of the respondents agreed with the proposition of 'the buildings should be lower in height'. These findings once again reveal that the conspicuousness of the external buildings affects the visual quality of the garden's scenery negatively.

The findings of this study indicate that planning and design actions to solve the problem is not urgent. However, if the visitors' judgments strongly support the hypothesis that the buildings devalue the garden scenery by the outcomes of further studies on this issue with extended variables, it is highly recommended that the city administration should initiate a comprehensive planning process. This situation leads to a phenomenon that must be dealt by participatory planning. Creating a solution that all stakeholders can agree on will result in more balanced urbanization as well as an increase in the quality of the experience in the heritage gardens. Therefore, in order to protect the value and sense of place in this important heritage garden, a reorganization of the land use in the surroundings of Hama-rikyu Gardens should be undertaken. For instance, when the buildings in the surroundings of this garden become deficient economically and physically in the future, the removal of these buildings would be an important and necessary action for both the city and the scenery from inside the garden. In this sense, the most important output of this study is that the city administration and garden management should seek for sustainable solutions for the issue in the long term.

It is regrettable that the sceneries of traditional Japanese gardens in Tokyo, which are an important value not only for the country but for the whole world, has fallen victim to modern urbanization. Even so, as the idiom 'it is never too late to mend' reminds us, it should not be forgotten that learning from the mistakes made in the past can enable us to create sustainable environments for the future.

\section{Acknowledgments}

The field survey was made possible by the allowance of Tokyo Metropolitan Government Park Association, Division of Cultural Property Gardens/ Hama-rikyu Gardens. Support from the manager of Hama-rikyu Gardens, Ms. Nakayama Natsuki and the staff in the garden office is gratefully acknowledged. We would also show our gratitude to Ms. Sofia Penabaz-Wiley and Ms. Libo He for assistance with in-situ survey and Ms. Mayu Tatsuki and Mr. Mitsunari Terada for their help in preparing Japanese version of the questionnaire.

\section{REFERENCES}

[1] Lefebvre H. La vie quotidienne dans le monde moderne. (In Turkish: Modern Dünyada Gündelik Hayat), (Gürbüz I, trans.), 2nd ed, Metis, Istanbul, p.39, 1996.

[2] Bell S. Landscape: Pattern, Perception and Process. 2nd ed, Routledge, Oxon, p.63, 2012.

[3] Jinnai H. Tokyo: A spatial anthropology. 1st ed. Univ. of California Press, California, p.75, 1995.

[4] Brown A. Just Enough: Lessons in living green from traditional Japan. 2nd ed, Tuttle Publishing, Tokyo, p. 54, 2013.

[5] Shirahata Y. Daimyo garden. (Imoto Chikako and Kynne E. Riggs, trans.) International Research Center for Japanese Studies, pp.85-135, 2016.

[6] Arifin NH. A study on the visual landscape conservation of Japanese daimyo gardens: a case study in Ritsurin garden, Takamatsu city, Japan. PhD Thesis, Ehime University, Japan, 1998.

[7] Ito $T$ and Kawarada M. Environmentalism in Japanese gardens. In: Conan M (ed.) Environmentalism in landscape architecture. 1st ed. Dumbarton Oaks Research Library and Collection, Washington, pp.245-268, 2000.

[8] Sullivan C and Boults E. Illustrated history of landscape design. 1st ed. John Wiley \& Sons, New Jersey, p.111, 2010.

[9] Nitschke G. Japanese gardens: right angle and natural form. 1st ed, Taschen, Köln, p.181, 1993.

[10] Shinji I, Shimizu T and Takemata T. The present situation of landscape destructions on the cultural property gardens in Tokyo. Journal of the Japanese Institute of Landscape Architects, Vol.52, No.5, 43-48, 1989.

[11] Arifin NH and Masuda T. The visual impact of building development on Ritsurin garden and its conservation. Landscape Research Japan, J. JILA, Vol.60, No.4, 315-323,1997. 
[12] Arifin NH and Masuda T. Visitors' judgments on the scenery of Ritsurin garden. Landscape Research Japan, J. JILA, Vol.61, No.3, 259-262, 1998.

[13] Koizumi M and Ishikawa M. A study of landscape structure in Dai-sensui and Yokobori area of Hamarikyu Garden [Tokyo, Japan]. Journal of the Japanese Institute of Landscape Architecture, LRJ, Vol.70, No.5, 497-500, 2007.

[14] Shinobe H. A study on the scenery protection around the garden in the city - case study of five traditional Japanese landscape gardens. Journal of the City Planning Institute of Japan, Vol.47, No.3, 625-630, 2012.

[15] Lin L, Homma R and Iki K. Visual Impact Analysis and Control Method of Building Height for Landscape Preservation of the Traditional Gardens: A Case Study on the Suizenji Jojuen in Kumamoto City. In: Pan Q and Li W (eds) Smart Growth and Sustainable Development. Springer International Publishing, pp.115-125, 2017.

[16] Online available: 高層ビルが借景に (High-rise buildings to borrow) [Web log post], Online available from https://www.tripadvisor.jp/ShowUserReviews-g1066451-d 2075268-r322242222-Former_Shiba_Rikyu_Garden Minato Tokyo Tokyo Prefecture Kanto.html [Accessed 24 August 2017].

[17] Online available: New ebook! Hamarikyu Garden, Online available from

https://realjapanesegardens.wordpress.com/2015/09/24/new -ebook-hamarikyu-garden/ [Accessed 19 December 2017].

[18] Online available: A modern concept of 'Shakkei', Online available

from:

https://realjapanesegardens.wordpress.com/2016/01/20/a-m odern-concept-of-shakkei/ [Accessed 24 August 2017].

[19] Online available: Hamarikyu Gardens - A Secret Japanese Gardens in the Heart of Tokyo, Online available from: https://fastjapan.com/en/p110439 [Accessed 27 October 2017].

[20] Akasaka, M. Whose view to Mount Fuji is in Tokyo?. In: Dobričič, S., Magnani, C., Pedroli, B., \& Strecker, A (eds). The Issues on the Vistas in Townscapes. I Quaderni Di Careggi, Vol.6, No.6, 9-14, 2014. Online available from http://graspthefuture.eu/wp-content/uploads/2017/03/6-201 4-UNISCAP6-E-KR-Quaderni-di-Careggi-Sixth-issue-Com mon-Goods.pdf [Accessed 25 December 2017].

[21] Meinig DW. The beholding eye: Ten versions of the same scene. Landscape Architecture, Vol.66, 47-54,1976.

[22] Dupré J. Skyscrapers. Black Dog \& Leventhal Pub, New York, p.119, 1996.

[23] Parker M. Vertical capitalism: Skyscrapers and organization. Culture and Organization, Vol.21, No.3, 217-34, 2015.

[24] Gifford R, McCunn LJ. Appraisals of built environments and approaches to building design that promote well-being and healthy behavior. In: Steg L., Van den Berg A. E. and De Groot J.I.M. (eds) Environmental psychology: An introduction. 1st ed, Wiley, Sussex, pp.87-96, 2012.

[25] Nasar J. Urban design aesthetics: The evaluative qualities of building exteriors. Environment and Behavior, Vol.26, No.3, 377-401, 1994.
[26] Stamps AE. All buildings great and small: Design review from high-rise to houses. Environment and Behavior, Vol.26, No.3, 402-420, 1994.

[27] Kaplan R and Kaplan S. The experience of nature: A psychological perspective. 2nd ed, Ulrich, Michigan, p.42, 1995.

[28] Kaplan R, Kaplan S and Ryan RL. With people in mind: Design and management of everyday nature. 1th ed, Island, Washington, p.31,1998.

[29] Nasar J. The evaluative image of the city. 1th ed, Sage Publications, California, p.25,1998.

[30] Nasar J. Symbolic meanings of house styles. Environment and behavior, Vol.21, No.3, 235-257, 1989.

[31] Daniel TC and Vining J. Methodological issues in the assessment of landscape quality. In: Altman I and Wohlwill JF (eds) Behavior and the natural environment.1th ed, Plenum, New York, pp.39-84,1983.

[32] Tokyo Metropolitan Park Association (2008). Hama-rikyu Gardens. Online available from http://teien.tokyo-park.or.jp/en/hama-rikyu/outline.html [Accessed 24 August 2017].

[33] Shinji I (2015). What is a daimyo teien?: The ideal Edo period garden, combining form and function. Online available from

http://jqrmag.com/en/feature/what-is-a-daimyo-teien-the-id eal-edo-period-garden-combining-form-and-function/ [Accessed 29 August 2017].

[34] Tokyo Metropolitan Government Bureau of Construction Park Division (2017). The cultural asset gardens in Tokyo, preservation utilization plan (Hama-rikyu Gardens) http://www.kensetsu.metro.tokyo.jp/content/000027750.pdf [Accessed 10 August 2017].

[35] Nasar J L, Julian D, Buchman S, et al. The emotional quality of scenes and observation points: A look at prospect and refuge. Landscape Planning, Vol.10, No.4, 355-361, 1983.

[36] Ruddell EJ and Hammitt WE. Prospect refuge theory: A psychological orientation for edge effect in recreation environments. J Leisur Res, Vol.19, No.4, 249-260, 1987.

[37] Conrad J. Prospect/refuge theory: An experimental approach. $\mathrm{PhD}$ Thesis, Queensland University of Technology, Brisbane, 1993.

[38] Hagerhall CM. Clustering predictors of landscape preference in the traditional Swedish cultural landscape: prospect-refuge, mystery, age and management. Journal of Environmental Psychology, Vol.20, No.1, 83-90, 2000.

[39] Stamps AE and Nasar J. Design review and public preferences: Effect of geographical location, public consensus, sensation seeking and architectural styles. Journal of Environmental Psychology, Vol.17, No.1, 11-32, 1997.

[40] Tokyo Metropolitan Government Bureau of Construction Park Division (2017). The cultural asset gardens in Tokyo, preservation utilization plan (common edition) http://www.kensetsu.metro.tokyo.jp/content/000027743.pdf [Accessed 18 August 2017]. 